\title{
Chapter 6 \\ Tracking Climate Change Vulnerability at Municipal Level in Rural Haiti Using Open Data
}

\author{
Maurizio Tiepolo and Maurizio Bacci
}

\begin{abstract}
In Least Developed tropical Countries, the vulnerability assessment to climate change (CC) at local scale follows an indicator-based approach and uses information gathered mainly through household surveys or focus groups. Conceived in this way, the vulnerability assessment is rarely repeatable in time, cannot be compared with those carried out in other contexts and usually has low spatial coverage. The growing availability of open data at municipal level, routinely collected, now allows us to switch to vulnerability tracking (continuous, low cost, consistent with global monitoring systems). The aim of this chapter is to propose and verify the applicability of a VICC-Vulnerability Index to Climate Change on a municipal scale for Haiti. The chapter identifies open data on national, departmental and municipal scale, selects the information on a municipal scale on the basis of quality, identifies the indicators, evaluates the robustness of the index and measures it. The index consists of 10 indicators created using information relating to monthly precipitations, population density, flood prone areas, crop deficit, farmers for self-consumption, rural accessibility, local plans for CC adaptation, irrigated agriculture and cholera incidence. This information is gathered for the 125 mainly rural municipalities of Haiti. The description and discussion of the results is followed by suggestions to improve the index aimed at donors, local authorities and users.
\end{abstract}

Keywords Climate planning - Local governments · SPI • Vulnerability index

M. Tiepolo authored all the sections with the only exception of section 6.2.4 Indicators 1 and 2, authored by M. Bacci.

M. Tiepolo ( $₫)$

DIST, Politecnico and University of Turin, Viale Mattioli 39, Turin 10125, Italy

e-mail: maurizio.tiepolo@polito.it

M. Bacci

National Research Council-Institute of BioMeteorology (IBIMET),

Via Giovanni Caproni 8, 50145 Florence, Italy

e-mail: M.Bacci@ibimet.cnr.it 


\subsection{Introduction}

Vulnerability is "the propensity or predisposition to be adversely affected" (IPCC 2014: 128) and is estimated in various sectors: food security (OCHA, WFP and FEWSNET), environment, agriculture, livelihood. Here we're going to look at vulnerability to climate change (CC), in other words, "to a change in the state of the climate that can be identified by changes in the mean and or the variability of its properties and that persists for an extended period, typically decades or longer" (IPCC 2014: 120). Vulnerability to CC is related to people. Ascertaining it is important for decision making related to adaptation measures and subsequent monitoring and evaluation.

Vulnerability to $\mathrm{CC}$ at local scale is usually ascertained with a vulnerability index with a variable number of indicators: from 10 to 33 (Hahn et al. 2009; RdH, MARNDR 2009; Gabetibuo et al. 2010; Sharma and Jangle 2012; Borja-Vega et al. 2013; Etwire et al. 2013; PNUMA 2013; Ahsan and Warner 2014; Bollin et al. 2014). The more indicators we have (namely those created especially to appreciate vulnerability), the harder it is to repeat the assessment in time and replicate it in other contexts (Table 6.1). In actual fact, decision making and monitoring need to track vulnerability more than assess it occasionally.

To satisfy these requirements, we need open data on a small geographic area, routinely collected at low cost (World Bank 2014), of which we know the metadata. The ideal scale is that of municipalities, as these are the administrative jurisdictions closest to the impacts of $\mathrm{CC}$ and with specific tasks in the field.

Haiti is the 4th most vulnerable country to CC (Verisk Maplecroft 2016). The projections of the IPCC for the Caribbean region to which Haiti belongs suggest about a $1.2-2.3{ }^{\circ} \mathrm{C}$ increase in surface temperature, a decrease in precipitations of about $5 \%$, and a sea level rise of between 0.5 and $0.6 \mathrm{~m}$ by 2100 compared to the baseline 1986-2005 (Nurse et al. 2014: 1627-8). If these changes should take place, the economic impacts on export crops (coffee and mango), on the availability of water resources and on health would be tremendous (Borde et al. 2015). Tracking vulnerability to $\mathrm{CC}$ on a municipal scale in Haiti is particularly helpful, because the aid that the country benefits to adapt to $\mathrm{CC}$ risk being repeatedly channelled to the same areas, without reaching the most vulnerable municipalities. In Haiti today, the vulnerability assessment is practiced on a national and departmental scale. But the departments (from 1268 to $5000 \mathrm{~km}^{2}$ ) contain greatly diverse territories. The South East department, for example, runs from the coast to mountain chains than exceed an altitude of 2200 metres in just $2000 \mathrm{~km}^{2}$. On the contrary, the municipal scale is small enough (from 22 to $639 \mathrm{~km}^{2}$ ) for tracking which is also helpful to local projects.

The idea of measuring vulnerability at municipal scale isn't new in Haiti. In 2009, the National council for food security-CNSA (Ministry of agriculture), in collaboration with FEWS NET, produced a vulnerability index on a municipal scale (RdH, CNSA-MARNDR 2009). However, the assessment was carried out only then and we have no knowledge of the metadata of the indicators to be able to continue it. 
The MPCE and ONPES Basic statistics program, funded by the European Union, aimed mainly at the national poverty reduction strategy, is expected to generate useful information, but at the moment there is no open data available. Different maps are now freely accessible at http://haitidata.org/ and routinely collected helpful information is available.

The aim of this chapter is to check the applicability of the vulnerability index to CC (VICC) on a municipal scale to Haiti, using routinely collected open data. The choice of the indicators that make up the index derives from the definition of vulnerability (V) as a function of three components: exposure, sensitivity and adaptive capacity.

Exposure (E) refers to "The presence of people, livelihoods, species or ecosystems, environmental functions, services, and resources, infrastructure, or economic, social, or cultural assets in places and settings that could be adversely affected." (IPCC 2014: 1765). Examples are flood or drought prone areas and population density.

Sensitivity (S) is "The degree to which a system or species is affected, either adversely or beneficially, by climate variability or change. The effect may be direct (e.g., a change in crop yield in response to a change in the mean, range, or variability of temperature) or indirect (e.g., damages caused by an increase in the frequency of coastal flooding due to sea level rise)." (IPCC 2014: 1772-73). Examples are anomalies in the prices of food, crop deficit, poverty, damage following hydro-climatic disaster or the number of farmers who grow crops to satisfy their own requirements only.

Adaptive capacity (AC) is "The ability of systems, institutions, humans, and other organisms to adjust to potential damage, to take advantage of opportunities, or to respond to consequences." (IPCC 2014: 1758). Examples are official development aid in the environmental sector, the reduction of illiteracy, forest surface dynamics, the existence of adaptation plans, rural infrastructures (irrigation, roads), safe housing, provided with drinking water, sanitation and hygiene facilities (WASH).

However, the irregularity of information, its availability at departmental level only and not freely accessible, means that most of these vulnerability dimensions are now impossible to survey at municipal level.

The VICC requires recognition of open data which has led to the identification of 10 vulnerability indicators on a municipal scale. The following paragraphs present, (ii) the methodology, which explains the meaning of the indicators selected, their characteristics and how the index is calculated, (iii) the results obtained with the vulnerability map at municipal level, and the advancements with respect to previous knowledge, (iv) the conclusions relating to perennial repetition, the expansion of the information needed to measure the index and the free availability of information. 


\subsection{Metodology}

Vulnerability is a function of Exposure (E), Sensitivity (S) and Adaptive capacity (AC) according to the Equation $\mathrm{V}=(\mathrm{E}+\mathrm{S})+(1-\mathrm{AC})$ already used by Heltberg et al. (2010), PNUMA (2013), Tuhladhar et al. (2013), USAID (2014), and UNESCO (2016). Every determinant is described by indicators. The process of indicator development is organised according to the steps suggested by Birkmann (2006), simplified here for operational use.

\subsubsection{Identification of the Open Data}

The open data useful to tracking vulnerability to $\mathrm{CC}$ in Haiti drops from 15 to 9 as we move from country to municipal scale. At least one third of the information is not collected with annual frequency, a quarter of the information is supplied by multi-bilateral organisms (CHIRPS, CRED, OECD, FAO, UNDP) (Table 6.2), and two third is freely available (Table 6.3)

\subsubsection{Indicator Performance}

The open data at municipal scale on Haiti clearly grasps the vulnerability of infrastructures, the population and agriculture, but not of health and nutrition, education, natural resources and ecosystems highlighted by Adger et al. (2004), nor the urban vulnerability.

As regards the temporal resolution of certain indicators (monthly precipitations, crop failure, adaptation planning) it is preferable to consider a period of time rather than just one year (for example, the five years following the earthquake of 2010). The drought magnitude and wet extremes have been observed over the past 35 years. In other cases, the indicators refer to a specific year (population density, rural accessibility, irrigated agriculture, farmers for self-consumption, cholera incidence).

\subsubsection{Selection Criteria for the Set of Potential Indicators}

The selection of the indicators must be led by clear criteria which allow the preliminary assessment of each individual indicator (Schiavo-Campo 1999; Hilden and Marx 2013): the pertinence of the indicator with CC, its accurate description (metadata), data availability and regular updating, spatial coverage (to what extent the municipalities are covered), the length of time series and temporal resolution, 
intelligibility (an indicator which is comprehensible and easy to understand without a deep knowledge of how it has been constructed) (Table 6.4).

\subsubsection{Identification of the Indicators}

The VICC for the municipalities of Haiti consists of the 10 indicators described below.

\section{Indicator 1-Drought Magnitude}

The severity of drought between 2011 and 2015 is a factor of exposure to CC. For various reasons, including the 2010 earthquake, Haiti does not have a rain gauge network on a municipality scale, with at least a thirty-year series of data up to the present day. The stations are managed by various organisations (CNIGS, CNSA, ONEV, SNRE, etc.), which do not provide open data.

An alternative solution, now frequent in climatic studies, is to use datasets of satellite rainfall estimation. Many institutions and research organisations make this information available free of charge or in exchange for payment. The Climate Hazards group with InfraRed Precipitation Stations (CHIRPS) v2 by the U.S. Geological Survey and Earth Resources Observation and Science incorporates $0.05^{\circ}$ resolution satellite imagery with in situ station data to create gridded rainfall time series (Funk et al. 2015). CHIRPS is a quasi-global daily dataset spanning $50^{\circ} \mathrm{S}-50^{\circ} \mathrm{N}$ and a daily resolution over the period 1981-2016 is freely distributed. These characteristics enable the description of rainfall dynamics in each municipality of Haiti with 36 years of data available. Free access offers the chance to update the VICC in future.

We have determined the centroid of every municipality (geometric centre of a two-dimensional figure through the mean position of all its points) using GIS software (Fig. 6.1) to extract from the CHIRPS 125 dataset series of rainfall (one for each municipality) from January 1981 to December 2015.

So we have calculated, according to the recommendations of the World Meteorological Organisation, the Standardised Precipitation Index (SPI) (WMO 2012). The SPI is based only on the probability of precipitation for any time scale. The index is standardized so that an index of zero indicates the average precipitation amount (50\% of the historical precipitation amount is below and $50 \%$ is above average) (Ci Grasp 2.0 2016). Positive SPI values indicate higher than average precipitation and negative values indicate less than average precipitation. Because the SPI is normalised, wetter and drier climates can be portrayed in the same way; thus, wet periods can also be monitored using the SPI.

The SPI is not linked to the absolute value of rainfall but to its distribution. An SPI of -2 can derive from a rainfall value of just a few millimetres in a semi-arid area or of several hundred millimetres in a very wet area. However, the SPI expresses how this value is more or less frequent than the historical series of 


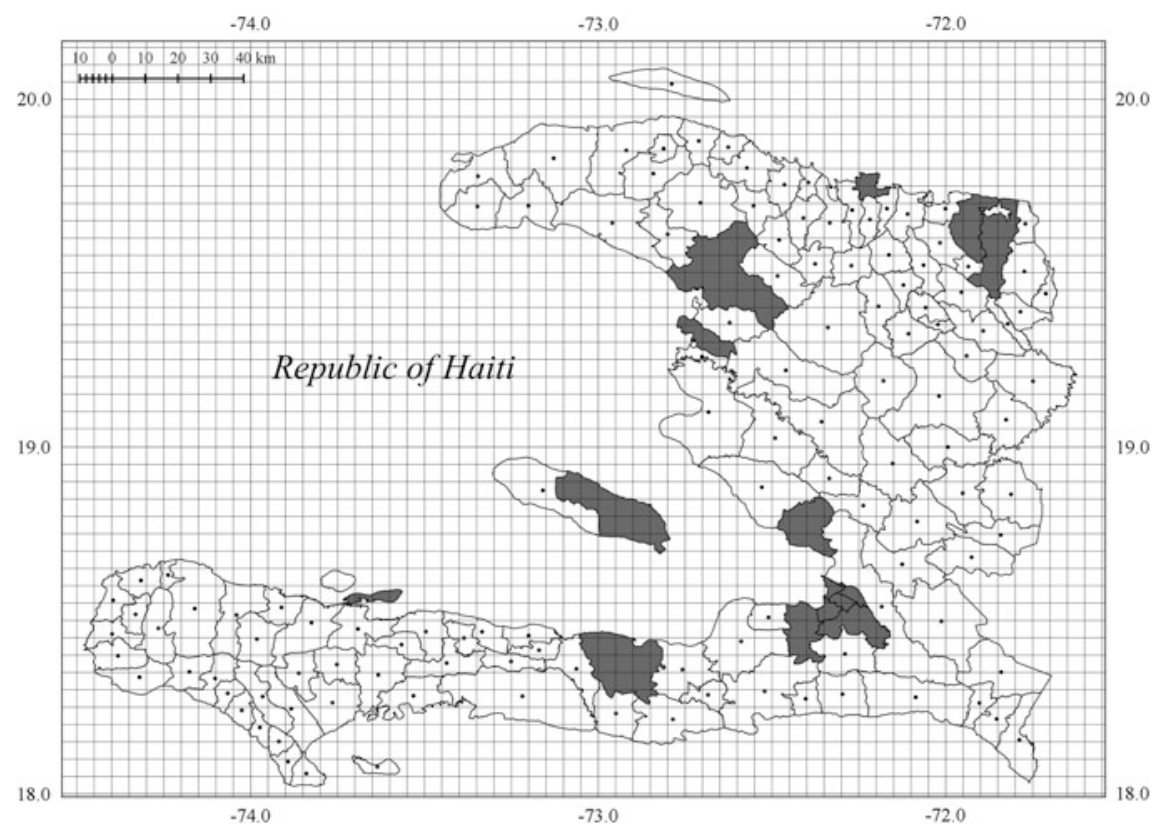

Fig. 6.1 Haiti. The grid of available information on monthly precipitation from CHIRPS showing the centroids (black dots) used for climate characterization of each municipality. Grey municipalities refers to municipalities with less than $33 \%$ of rural population not considered for this chapter

observation. Consequently, the availability of water resources for the population, for vegetation and for farming in the area will probably be jeopardised by phenomena which are very different from the normal distribution of rainfall, because the place has now adapted to a certain pluviometric regime.

A drought event occurs any time the SPI is continuously negative and reaches an intensity of -1.0 or less. The event ends when the SPI becomes positive. The positive sum of the SPI for all the months within a drought event can be referred to as the drought's "magnitude". SPI accumulated values can be used to analyse drought severity.

The SPI can be calculated on different timescales that reflect the impact of drought on the availability of the different water resources. Soil moisture conditions respond to precipitation anomalies on a relatively short scale. Groundwater, streamflow and reservoir storage reflect longer-term precipitation anomalies. In this case, a quarterly SPI was chosen, to intercept relatively prolonged drought phenomena which can jeopardise Haiti's water system and its agricultural crops. The accumulation of rainfall over three months, required to calculate the quarterly SPI, implicates the use of the previous two months to calculate the accumulation. January and February 1981 are missing from the CHIRPS historical series. 
Consequently, 1981 has 10 monthly SPI values. Almost all of 1995 is missing, so the SPI for that year was not calculated.

The report for the average value of the drought magnitude 2011-2015 (period of analysis) and its value for 1981-2010 (reference period), was calculated for every municipality. Subsequently, these values have been normalised on a scale of $0-1$ on the basis of the minimum and maximum value of the report recorded among all the municipalities (Petite Rivière des Nippes $1.04=0$, Belle Anse $3.42=1$ ). After calculating the drought magnitude, the map was produced (Fig. 6.2) using 4 classes: $0-0.24,0.25-0.49,0.50-0.74,0.75-1$.

\section{Indicator 2-Wet Extremes}

Extreme precipitations between 2011 and 2015 are an exposure factor of a municipality to $\mathrm{CC}$, in that they can generate flooding. The characterisation of every municipality with respect to extreme precipitations uses, like for drought, the CHIRPS dataset correspondence with the centroid of every municipality. In this case, the options available were to characterise the wet conditions using classic indexes of intense rainfall or using the 1-month SPI:

- R20 mm, number of days' rainfall in excess of $20 \mathrm{~mm} / \mathrm{year}$.

- R95p, number of days' rainfall higher than the 95th percentile/year (only during rainy events).

Very wet 1-month SPI (number of months/year with SPI > 1.5) and extremely wet (number of months/year SPI > 2). In this case too, the ratio of the 2011-2015 five-year average and the average for 1981-2010 was calculated for every municipality. Subsequently, these values are normalised on a scale of $0-1$, on the basis of the minimum and maximum. Every index presents positive and negative characteristics. R20 mm does not highlight significant changes in the various municipalities so $20 \mathrm{~mm}$ is not enough to intercept the dynamics of extreme rains in Haiti.

$\mathrm{R} 95 \mathrm{p}$ is more appropriate, in that it is based on the calculation of the distribution of rains in each individual municipality. However, it is a more sophisticated and harder to understand index. Moreover, its distribution in the municipalities of Haiti does not present very significant changes. 1-month SPI extremely wet (SPI > 2) highlight more changes in the municipalities than the 1-month SPI very wet (SPI $>1.5$ ). The 1-month SPI $>2$ is relatively easy to explain and understand. This is why the decision was made to use it to characterise the wet extremes (Fig. 6.2) according to 4 classes: $0-0.24,0.25-0.49,0.50-0.74,0.75-1$.

\section{Indicator 3-Flood Prone Areas}

Haiti has few vast areas exposed to river or marine flooding (North-East, Artibonite, North-East of Port-au-Prince, Cayes). The rest of the territory presents lots of flood prone areas which are small in size. We referred to the freely available mapping from the Centre National de 1'Information Géo-Spatiale-CNGIS in 2010, which shows the extent of Haiti flood prone areas, according to field observations, 

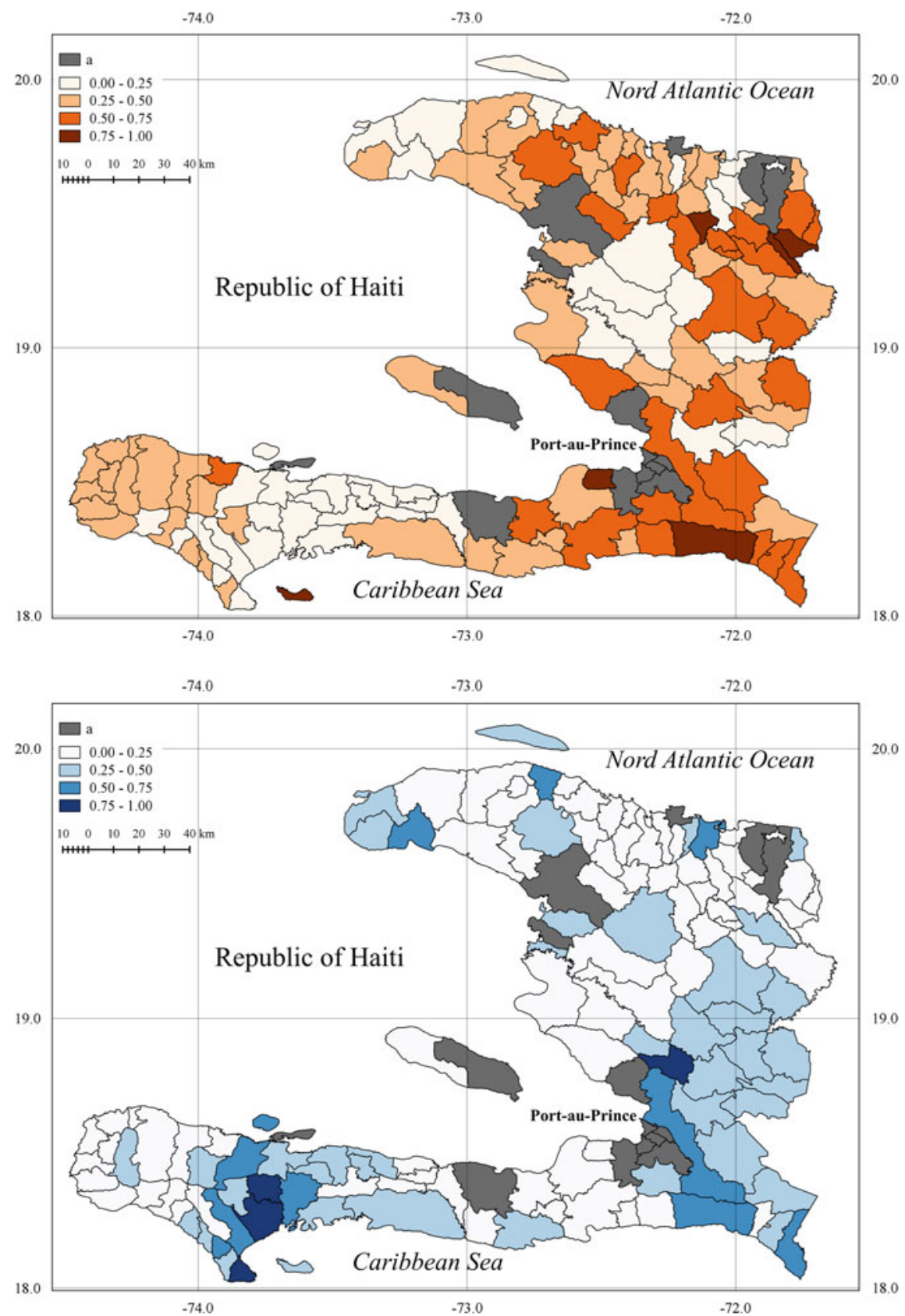

Fig. 6.2 Haiti, municipalities, 2011-2015. Drought magnitude (top) and wet extremes (bottom): a. urban municipalities 
historic and recent records as prepared by NATHAT 1 (May 2010), using Google Maps, and deterministically plotting the largest extent of flooding, according to a digital elevation model of $30 \mathrm{~m}$ pixels. The map, overlapping the municipal boundaries, shows that $72 \%$ of municipalities have flood prone areas. The flood prone areas have been related to the surface of every municipality and divided into four classes $(0-25,25-50,50-75,75-100 \%)$ for which the mean value has been chosen $(12.5,37.5,62.5,87.5)$ and then normalised on a scale from 0 to $1(0.25$, $0.50,0.75,1.00)$.

\section{Indicator 4-Population Density}

The rise in population density is an exposure factor: with the same territorial surface, a flood causes more damage to a denser population than to a widespread one. It is an indicator proposed also to monitor the Sustainable United Nations' Development Goals-SDGs (UNESC 2015). The density considered is that calculated by the IHSI-Institut Haïtien de Statistique et d'Informatique (RdH, MEF 2012). The value is normalised on a scale of $0-1$ depending on whether we start from the less densely populated municipality (Point à Raquette, 74 people per sq $\mathrm{km}=0$ ) or the most densely populated one (Saint Louis du Nord, 884 people per sq $\mathrm{km}=1$ ).

\section{Indicator 5-Crop Deficit}

Crop deficit is a sign of sensitivity to CC. It is recognised as being among the indicators of the 2nd SDG-End hunger, achieve food security and improved nutrition and promote sustainable agriculture (UNESC 2015). The Ministry of agriculture, natural resources and rural development (MARNDR, according to the French acronym) estimates crop production per department using experts, considering the useful farming surface area, sun exposure and other factors with a qualitative-quantitative methodology which is not clearly described. Total production expressed in equivalent cereals and that of the main crops (maize, rice, bananas, beans, potatoes) is the only information supplied in reports on spring crops per municipality (RdH, MARNDR 2014, 2013, 2012a, b and c; FAO-PAM 2010). For the purposes of constructing the VICC, we have used the total production per municipality in equivalent cereals referred to that of 2009 which, according to the MARNDR, was the best year in the last fifteen. For each municipality we assessed the deficit over five years: 2010, 2011, 2012, 2013 and 2014. Production is classified into 5 categories $(<50,50-70,70-90,90-110,110-130,>140 \%)$ referred to production in 2009 . We related these classes to the average value of each of them $(40,60,80,100,120$ and 140). Then we calculated the average production of every municipality during the five years. This value varies from 46 to $122 \%$. These values have been normalized on a scale of $0-1$ and then inverted, assigning the value of 1 to the lowest (46) and 0 to the highest (122). In this way, the values close to 1 show an average spring crop deficit of around $46 \%$ compared to that of 2009 . The basic information supplied by the spring campaign reports does not always follow the same standard. Production in 2012 for example was referred to that of the previous year. Therefore, it was necessary to relate it to 2009. Production for 2010 and 2014 
was referred to the registration sections (sub-category of the municipality). In this case, when the production values of the sections of a municipality were different, the mean value was calculated.

\section{Indicator 6-Farmers for Self-consumption}

Dependence exclusively on farming for subsistence is a sensitivity factor. This information is used by numerous scholars (Adger et al. 2004). The information is supplied by the MARNDR and is part of the Agricultural Atlas of Haiti $(\mathrm{RdH}$, MARNDR 2012a, b and c). The information is provided for five classes which we took to mean values of $80,60,40,22.5$ and 7.5 and then normalised on a scale from $0(7.5)$ to $1(80)$.

\section{Indicator 7-Local Development and Contingency Plans}

Among the adaptive capacities the first thing to consider is the capacity of the municipalities to plan the measures for adaptation to $\mathrm{CC}$ over a period time. This capacity is among the indicators of the SDG 11-Make cities and human settlements inclusive, safe, resilient and sustainable (indicator 11b1). Haiti's municipalities have basically three types of tools: Local development plans, Contingency plans and, occasionally, Comprehensive plans. The implementation of these plans requires the mobilisation of different players for financing. Freely available plans is important to encourage implementation. Recognition on internet has enabled the identification of 19 plans. We have assigned a value of 0 to municipalities with a plan and a value of 1 to those without a plan.

\section{Indicator 8-Irrigation Systems}

The use of irrigation systems in agriculture is an adaptive capacity which is important in a country like Haiti which, in recent years, has been particularly exposed to drought. The monitoring of the SDG 2-End hunger, achieve food security and improved nutrition and promote sustainable agriculture considers it (UNESC 2015). The Agricultural Atlas of Haiti supplies the amount of cultivable land that can be irrigated with respect to the cultivable area. The information is supplied according to five classes $(<5,5-15,15-30,30-60,>60 \%)$ which we have related to the mean values of every class $(2.5,12.5,22.5,45,75)$ and normalised on a scale of 0 (75)-1 (2.5).

\section{Indicator 9-Access to All-season Road}

Municipalities that are served by all-season roads which allow constant access to services that are not available in the place of residence is an adaptive capacity factor. The Rural Access Index (RAI) proposed by the World Bank (Roberts et al. 2006) and calculated by the MTPTC in May 2015 for every municipal section of Haiti (RdH, MTPTS 2015) is among the indicators proposed by the United Nations to monitor SDG 9-Build resilient infrastructure. The RAI expresses the percentage of population which, in every municipal subdivision (about 600 for the whole of Haiti) lives within $2 \mathrm{~km}$ from an all-season road. The information is supplied 
according to seven classes from $0-25 \%$ to $85-100 \%$. We calculated the average value for each class and, when a municipality is made up of sections with a different RAI, the average between the values of every section. Then the values were normalised on a scale of 0 to 1 and rearranged to attribute the maximum value (1) to the municipality with least accessibility $(0.13)$ and the minimum (zero) to the municipality with most accessibility (0.93).

\section{Indicator 10-Cholera Incidence}

Access to drinking water, sanitation and medical care expresses an adaptive capacity and forms the 6th SDG-Ensure availability and sustainable management of water and sanitation for all (UNESC 2015). Since there is a lack of open data on access to drinking water and to sanitation at municipal level, we used the cholera incidence as proxy indicator as its persistence "almost 6 years after its appearance, is largely due to the lack of access to safe drinking water and sanitation" (OCHA 2016: 3). This happens, for example, when sewage is dumped straight into the river and the river is used for drinking, irrigation, bathing and washing clothes (Frerichs 2016). Haiti, after the cholera peaks of 1.8 and 3.4\% in 2010 and 2011 respectively, has still not succeeded in weakening the epidemic, which worsened in 2015 $(0.4 \%$ ). The Ministry of Human health regularly publishes statistics by municipality. We used those for April-June 2015 (RdH, MSPP 2015), which presents the lowest incidence during the year and considered only municipalities with a cholera incidence higher than $0.1 \%$. The figures were normalised on a scale of $0-1$. Nineteen municipalities do not supply data because they do not have a local centre for the diagnosis and treatment of cholera. We did not think it is fair to proceed in these cases with the imputation of the missing data as the residents from these municipalities simply go to the nearest cholera diagnosis and treatment centres.

\subsubsection{Robustness and Applicability of the Index}

To ensure that all the indicators are comparable, we normalised the values of each indicator on a scale of 0 (minimum vulnerability) to 1 (maximum vulnerability) (Table 6.5). The indicators 5, 7 and 9 required the overturning of the value. We assigned an equal weight to each indicator, instead of using expert opinions (hard to trace for 125 municipalities) or statistical models like the PCA-Principal component analysis (which require capacities which the users of the index rarely have, whether they are donors or local authorities). The vulnerability index to $\mathrm{CC}$ on a municipal scale adds together the values of the single indicators of exposure (E), sensitivity (S) and adaptive capacity (AC) according to the equation $\mathrm{VICC}=(E+S)+(1-\mathrm{AC})=(i 1+i 2+i 3+i 4+i 5+i 6)+(1-(i 7+i 8+i 9+i 10))$ where $i 1$ is drought magnitude, $i 2$ is wet extremes, $i 3$ is flood prone areas, i4 is population density, $i 5$ is crop deficit, $i 6$ is farmers for self-consumption, $i 7$ is local 


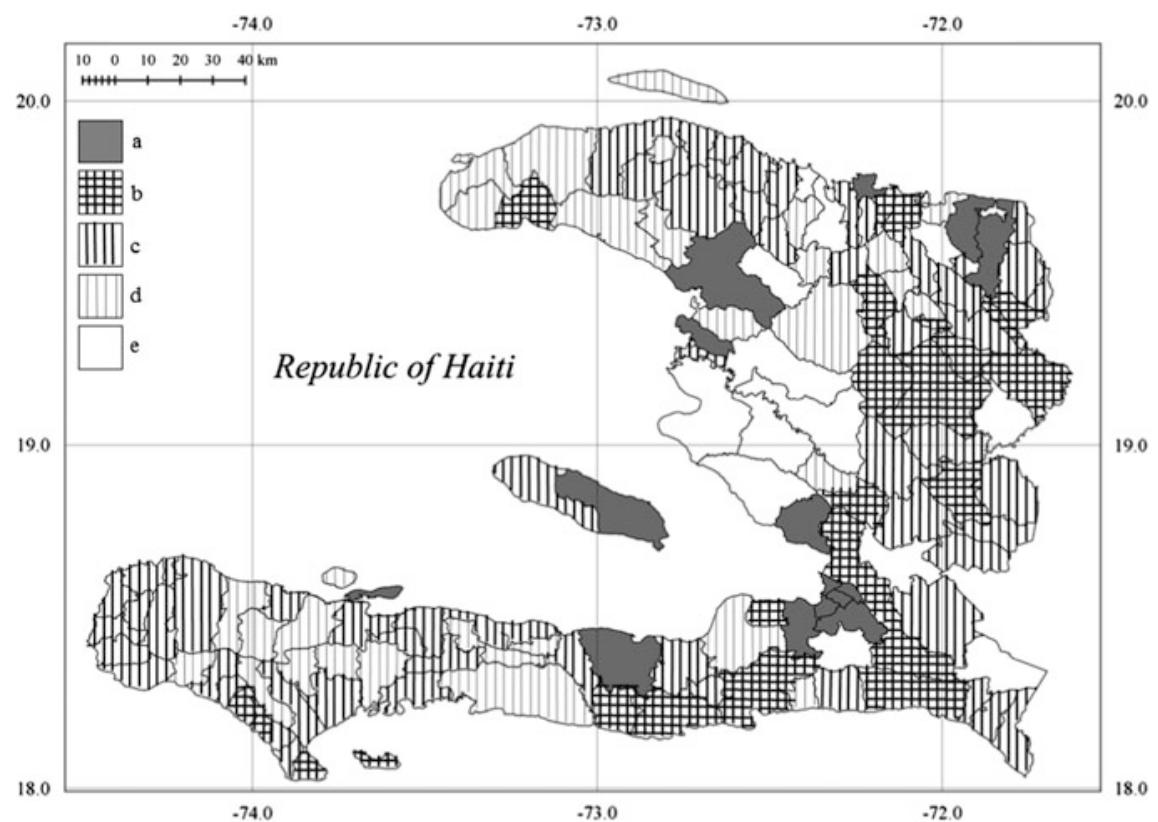

Fig. 6.3 Haiti, vulnerability to $\mathrm{CC}$ of the rural municipalities: a. urban, b. high, c. medium, d. low, e. very low

adaptation or contingency plans, $i 8$ is rural access, $i 9$ is irrigation systems, and $i 10$ is cholera incidence.

Vulnerability can take on a value of $0-10$. The real values go from 2.51 (Saint-Marc) to 6.32 (Baie de Henne) (Fig. 6.3; Table 6.8). Considering this distribution, we divided the ranges (3.81 point) into four equal parts corresponding to high, medium, low, and very low vulnerability (Table 6.6).

\subsection{Results and Discussion}

Vulnerability to $\mathrm{CC}$ is calculated for 125 rural municipalities in which $65 \%$ of Haiti's population lived in 2012. The remaining 15 municipalities (35\% of the population) are exclusively or mainly urban and have not been considered as they require different information to that used for the rural municipalities and, at the moment, this is not freely available. This said, while Port-au-Prince is the second largest Caribbean city, Haiti continues to be $51 \%$ rural.

Of the 125 municipalities considered, 24 (1.3 million inhabitants) are highly vulnerable to CC, 58 (2.9 million inhabitants) are medium vulnerable, 31 are low vulnerable (1.5 million inhabitants) and 12 are very low vulnerable to CC (1.2 millions of inhabitants). 
Table 6.1 The Haiti open data VICC compared with other conventional surveys to assess vulnerability to $\mathrm{CC}$

\begin{tabular}{|c|c|c|c|}
\hline \multirow{2}{*}{$\begin{array}{l}\text { Type of } \\
\text { information }\end{array}$} & \multicolumn{3}{|l|}{ Type of survey } \\
\hline & $\begin{array}{l}\text { Open data VICC } \\
\text { 2nd hand information }\end{array}$ & $\begin{array}{l}\text { Traditional } \\
\text { 2nd hand } \\
\text { information }\end{array}$ & $\begin{array}{l}\text { Household } \\
1 \text { st hand information }\end{array}$ \\
\hline Municipalities\# & Hundreds & Thousands & Few to dozens \\
\hline Information used & $\begin{array}{l}\text { Census, daily/weekly or } \\
\text { annual surveys }\end{array}$ & Census & $\begin{array}{l}\text { Households survey, } \\
\text { focus groups }\end{array}$ \\
\hline Indicators number & $10-13$ & 38 & $17-31$ \\
\hline Indicator weight & No & Yes & Experts, PCA \\
\hline Processing time & Weeks & Months & Months \\
\hline Staff & One-two & Unknown & Dozens \\
\hline Money use & $\begin{array}{l}\text { Freed for development } \\
\text { activities }\end{array}$ & Mapping & $\begin{array}{l}\text { Data collection and } \\
\text { processing }\end{array}$ \\
\hline Replicability & Yes & Yes & Rare/No \\
\hline Refresh rate & Annual-biennial & Decennial & No \\
\hline Example & This chapter & $\begin{array}{l}\text { PNUMA } \\
(2013)\end{array}$ & $\begin{array}{l}\text { Ahsan and Warner } \\
\text { (2014) }\end{array}$ \\
\hline
\end{tabular}

The municipalities highly vulnerable to $\mathrm{CC}$ are concentrated in the Centre department, and around Port-au-Prince. Most of these municipalities stretch across the mountain territories of the central Cordillière, the Montaignes Noires and, above all, the Chaine de la Selle, behind the capital city (Fig. 6.3).

The concentration of highly vulnerable municipalities in the hinterland of the capital city and a few kilometres from the main road linking Port-au-Prince to Cap Haitien should theoretically simplify the reduction of vulnerability, as the materials needed for the adaptation works do not require movement over long distances, which would be necessary to reach the southwest and northwest areas of the country.

The calculation of the VICC allows further considerations on its single components, starting with exposure. From 2013 to 2015, Haiti was struck by the worst drought in the past 35 years, which peaked in 2014. The drought increased the number of dry months in a year which, in Belle Anse, went from three (1981-2010) to nine (2011-2015), in Bahon from three to eight, in Carice, Gressier and Mont Organisé from three to seven and in Ile à Vache from three to six (Fig. 6.3). This drought affected all the municipalities. In the previous twenty years, there had only been three isolated years of drought $(1997,2000,2009)$.

The drought caught the Haitians off-guard, unprepared for an event of such magnitude. The 2013-2015 drought was preceded by two extremely wet years. This however was not an effect of CC, because Haiti frequently has two extremely wet years in a row, due to its position on the hurricane route.

As regards others factors of exposure, the flood prone area exceeds $75 \%$ of the municipal surface area in Caracol, Cayes, Ferrier and Grande Saline, and between 50 and $75 \%$ of the municipal surface area in Estère, Milot and Saint Raphaël. The 
Table 6.2 Haiti 2015. Open data relevant for vulnerability tracking according administrative level

\begin{tabular}{|c|c|c|c|c|}
\hline \multirow{2}{*}{$\begin{array}{l}\text { Vulnerability } \\
\text { determinants }\end{array}$} & \multirow[t]{2}{*}{ Open data } & \multicolumn{3}{|c|}{ Administrative level } \\
\hline & & Country & Department & Municipality \\
\hline \multirow[t]{3}{*}{ Exposure } & Monthly precipitations & $\bullet$ & & 0 \\
\hline & Flood prone areas/unit area & $\bullet$ & 0 & 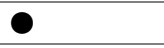 \\
\hline & Population density & 0 & 0 & ○ \\
\hline \multirow[t]{5}{*}{ Sensitivity } & Anomalies in food prices & & 0 & \\
\hline & Crop deficit & & & 0 \\
\hline & $\begin{array}{l}\text { Farmers cropping for } \\
\text { self-consumption }\end{array}$ & & & ○ \\
\hline & Poverty & - & 0 & \\
\hline & Victims of hydro climatic disaster & 0 & & \\
\hline Adaptive & ODA in environmental sector & 0 & & \\
\hline \multirow[t]{11}{*}{ capacity } & HDI-Human development index & ○ & & \\
\hline & Maternal mortality & ○ & 0 & \\
\hline & HIV Incidence & 0 & 0 & \\
\hline & Literacy rate & 0 & & \\
\hline & School enrolment according gender & - & 0 & \\
\hline & Forest area & $\bullet$ & & \\
\hline & Local plans for climate adaptation & 0 & 0 & 0 \\
\hline & Rural accessibility & & & ○ \\
\hline & Irrigated agriculture & ○ & 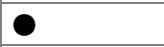 & 0 \\
\hline & Water and sanitation & 0 & 0 & \\
\hline & Cholera incidence & 0 & 0 & ○ \\
\hline
\end{tabular}

density of the population peaks in Saint Louis du Nord and is high in Limonade, Quartier Morin, Ferrier (Nord), Grande Saline (Artibonite), Croix des Bouquets (West), Belle Anse (South East) and Ile à Vache (South).

Rural sensitivity consists in two aspects. First, $65 \%$ of the municipalities had crop deficits between 2010 and 2014, with very severe deficits in six municipalities (crop yield of less than 46\% compared to 2009): Cerca Carvajal, Gressier, La Victoire, La Vallée, Maïssade and Saint Raphaël. Second, 16 municipalities have over $70 \%$ of farmers cultivating for self-consumption only.

In relation to adaptive capacity, just nineteen municipalities have a local development or contingency plan. Thirty-eight municipalities have no irrigation systems and only two have irrigated farming on over $60 \%$ of the useful farmland (La Victoire and Milot).

Eighty-four municipalities $(67 \%)$ have very little accessibility to an all-season road. Five municipalities have a very high cholera incidence $(>10 / 10,000)$ : Baie de Henne, Anse d'Hainault, Croix de Bouquets, Hinche and Quartier Morin. These 
Table 6.3 Haiti 2016. Freely available data to build indicators for vulnerability to CC tracking

\begin{tabular}{|c|c|c|}
\hline $\begin{array}{l}\text { Vulnerability } \\
\text { components }\end{array}$ & Information & Available at \\
\hline \multirow[t]{3}{*}{ Exposure } & $\begin{array}{l}\text { Monthly } \\
\text { precipitation }\end{array}$ & http://chg.geog.ucsb.edu/data/chirps/ \\
\hline & $\begin{array}{l}\text { Flood prone } \\
\text { areas }\end{array}$ & http://haitidata.org/layers/cnigs.spatialdata:hti \\
\hline & $\begin{array}{l}\text { Population } \\
\text { density }\end{array}$ & http://www.ihsi.ht/produit_demo_soc.htm \\
\hline \multirow[t]{2}{*}{ Sensitivity } & Crop deficit & $\begin{array}{l}\text { http://agriculture.gouv.ht/statistiques_agricoles/Atlas/ } \\
\text { thematiques_speciphiques.html }\end{array}$ \\
\hline & $\begin{array}{l}\text { Farmer } 4 \\
\text { self-consumption }\end{array}$ & $\begin{array}{l}\text { http://agriculture.gouv.ht/statistiques_agricoles/Atlas/ } \\
\text { thematiques_speciphiques.html }\end{array}$ \\
\hline Adaptive & Plans for CCA & \\
\hline \multirow[t]{3}{*}{ capacity } & $\begin{array}{l}\text { Rural } \\
\text { accessibility }\end{array}$ & $\begin{array}{l}\text { http://www.mtptc.gouv.ht/media/upload/doc/ } \\
\text { publications/ROUTE_INDICE-RAI-2015.pdf }\end{array}$ \\
\hline & $\begin{array}{l}\text { Irrigation } \\
\text { systems }\end{array}$ & $\begin{array}{l}\text { http://agriculture.gouv.ht/statistiques_agricoles/Atlas/ } \\
\text { thematiques_speciphiques.html }\end{array}$ \\
\hline & $\begin{array}{l}\text { Cholera } \\
\text { incidence }\end{array}$ & $\begin{array}{l}\text { http://mspp.gouv.ht/site/downloads/Bulletin\% } \\
\text { 20Trimestriel\%20MSPP\%20Juillet\%202015\% } \\
\text { 20version\%20web\%20compressed.pdf }\end{array}$ \\
\hline
\end{tabular}

four indicators highlight the municipalities with less adaptive capacity (Baie de Henne, Cerca la Source, Mirabelais and Thomonde, Ila à Vache, Anse d'Hainault) and those with more adaptive capacity (Bas Limbé, Saint-Marc, Petite Rivière de l'Artibonite, Kenscoff and Léogane).

The comparison between exposure and adaptive capacity (Fig. 6.4) highlights that there is no relationship between the two determinants. Therefore, the adaptive capacity does not respond to exposure to $\mathrm{CC}$. This awareness alone justifies the need for a VICC for Haiti at municipal level if we need to help decision making with regard to the adaptation of the most exposed municipalities. VICC on a municipal level presents rather different results when compared with the previous maps of the single determinants of vulnerability.

The map of drought magnitude 2011-2015, for example, is completely different from that of drought susceptivity 2010 ( $\mathrm{RdH} 2010: 18)$. The difference is due to the greater precision of our study, the different methodology, and the fact that the period that we considered was influenced by very severe drought, something which had not occurred in the previous 20 years. Another example is crop deficit. 
Table 6.4 Evaluation criteria for vulnerability indicators at municipal level

\begin{tabular}{|c|c|c|c|c|c|c|}
\hline \multirow[t]{2}{*}{ Indicator } & \multicolumn{6}{|c|}{ Evaluation criteria } \\
\hline & Pertinence & Metadata & $\begin{array}{l}\text { Availability } \\
\& \text { updating }\end{array}$ & $\begin{array}{l}\text { Spatial } \\
\text { coverage }\end{array}$ & Length & Intelligibility \\
\hline $\begin{array}{l}\text { Drought } \\
\text { magnitude }\end{array}$ & 5 & 5 & 5 & 5 & 5 & 4 \\
\hline Wet extremes & 5 & 5 & 5 & 5 & 5 & 4 \\
\hline $\begin{array}{l}\text { Flood prone } \\
\text { areas }\end{array}$ & 5 & 1 & 2 & 5 & 1 & 5 \\
\hline $\begin{array}{l}\text { Population } \\
\text { density }\end{array}$ & 5 & 5 & 5 & 5 & 3 & 5 \\
\hline $\begin{array}{l}\text { Agricultural } \\
\text { production }\end{array}$ & 5 & 5 & 5 & 5 & 4 & 5 \\
\hline $\begin{array}{l}\text { Farmers for } \\
\text { self-consumption }\end{array}$ & 5 & 1 & 5 & 5 & 1 & 5 \\
\hline Plans for CCA & 5 & 5 & 5 & 5 & 2 & 5 \\
\hline $\begin{array}{l}\text { Rural } \\
\text { accessibility }\end{array}$ & 5 & 3 & 3 & 5 & 1 & 5 \\
\hline $\begin{array}{l}\text { Irrigated } \\
\text { agriculture }\end{array}$ & 5 & 1 & 5 & 5 & 2 & 5 \\
\hline $\begin{array}{l}\text { Cholera } \\
\text { incidence }\end{array}$ & 5 & 1 & 5 & 4 & 2 & 5 \\
\hline
\end{tabular}

Metadata: 1 weakly documented, 3 methodology documented but not freely available. Availability \& updating: 2 routine collection does not exist, indicative information on accuracy, 3 data supposed routinely collected and freely available, 5 data routinely collected and freely available. Spatial coverage: 4 data unavailable on $15 \%$ of municipalities. Length: 1 one year available only, 2 two years available, 3 three years available, 4 four years available, 5 over 30 years available without interruptions. Intelligibility: 4 easily understood without expert knowledge

The municipalities that presented the highest food scarcity in 2009 (RdH, MARNDR 2009: 18) are not the same ones that presented the worst crop deficit between 2010 and 2014. The difference depends on the methodology but also on the fact that 2009 was one of the best agricultural years in the last fifteen.

The VICC is useful to all those projects which have such a dimension and duration as to justify a device for the assessment of their actions.

VICC can be also used to direct action. The municipalities with the highest score for crop deficit, local plans, irrigated surface area, RAI and cholera incidence are those that require most support to agriculture, to local development and contingency plans, road accessibility, irrigation systems and WASH.

The VICC can be improved by adding information on sensitivity (food prices, victims of disasters) and adaptive capacity (forested area, school enrolment, HIV incidence) which is currently available at national or departmental level only. 
Table 6.5 Indicators value according information organization

\begin{tabular}{l|l|l}
\hline $\begin{array}{l}\text { Vulnerability } \\
\text { indicator }\end{array}$ & Available information & Indicator range \\
\hline 1 Drought magnitude & & $1-0$ \\
\hline 2 Wet extremes & & $1-0$ \\
\hline 3 Flood prone areas & $<25,25-50,50-75,75-100$ & $1-0$ \\
\hline 4 Population density & $884-74$ inhabitants $/ \mathrm{km}^{2}$ & $1-0$ \\
\hline 5 Crop deficit & $70-90,50-70,<50 \%$ & $0.8,0.4,0.2$ \\
\hline 6 Farmers 4 & $>70,50-70,30-50,15-30,<15 \%$ & $1-0$ \\
self-consumption & Y/N & $1-0$ \\
\hline 7 Local CCA plans & $0-25,26-35,36-45,46-55,56-65$, & $0.87,0.7,0.6,0.5,0.4,0.3$, \\
\hline 8 Rural access & $66-75,75-100$ & 0.12 \\
\hline 9 Irrigation systems & $<5,5-15,15-30,30-60,>60 \%$ SAU & $0.3,0.13,0.28,0.45,0.8$ \\
\hline 10 Cholera incidence & $\begin{array}{l}0,1-2,2-5,5-10,>10 / 10,000 \\
\text { monthly }\end{array}$ & $0,0.15,0.35,0.8,1$ \\
\hline
\end{tabular}

Table 6.6 Robustness of the vulnerability index to CC for Haitian municipalities

\begin{tabular}{l|l}
\hline Robustness & Choices \\
\hline Indicators number & 10 \\
\hline Indicator exclusion/inclusion & According the evaluation criteria (Table 6.4) \\
\hline Normalization scheme & Each indicator is normalized in a 0-1 scale \\
\hline Indicators' weights & Equal weights \\
\hline Missing data & $\begin{array}{l}\text { Indicators 1 and 3: one year (1995) missing } \\
\text { Indicator 10: nineteen municipalities missing }\end{array}$ \\
\hline Imputation of missing data & No \\
\hline Aggregation method & Additive \\
\hline
\end{tabular}

The VICC can be improved also by refining the single indicators. For example, drought magnitude can be calculated as the average of several cells for the bigger municipalities (43\%). The RAI can be drastically improved by using the IRA (Tiepolo 2009): an indicator which considers the demographic weight of the towns and their distance from an all-season road, and can be set up after desk work only, without the costs and errors caused by the sample surveys that the indicators used by the World Bank requires (Table 6.7). 


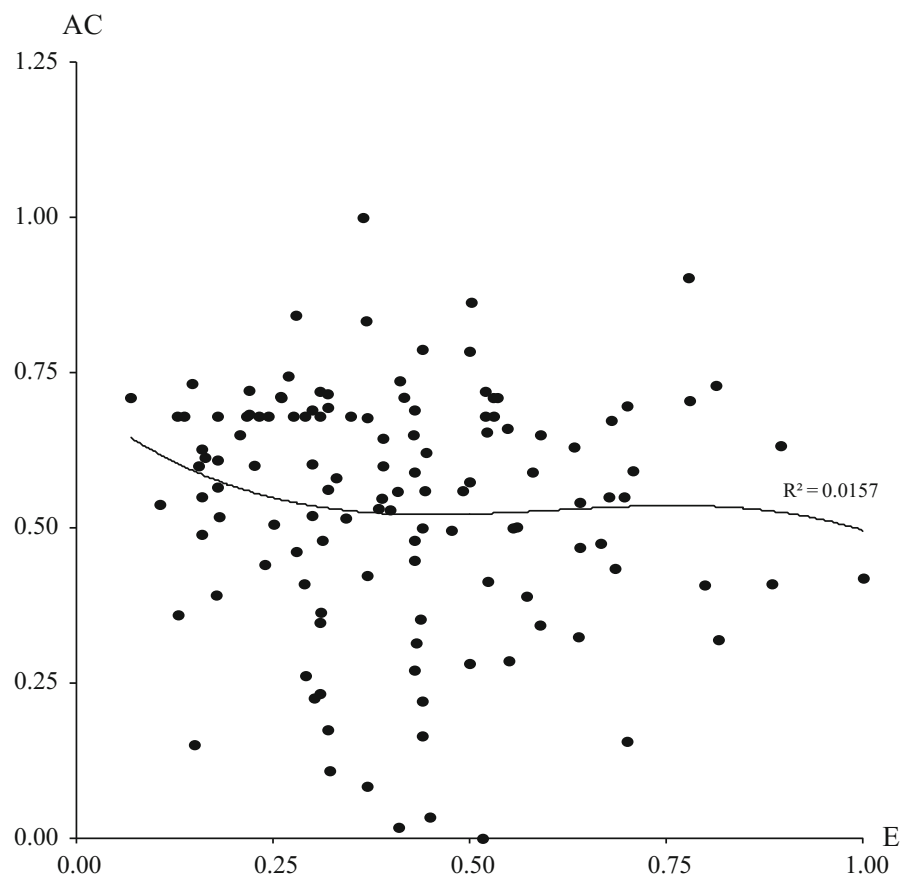

Fig. 6.4 Haiti, municipalities. Exposure (4 indicators) and adaptive capacity (4 indicators)

Table 6.7 Improvement of the indicators of vulnerability to CC

\begin{tabular}{|c|c|c|c|c|}
\hline $\begin{array}{l}\text { Vulnerability } \\
\text { determinants }\end{array}$ & \multirow{2}{*}{$\begin{array}{l}\text { Country } \\
\text { Existing }\end{array}$} & \multirow{2}{*}{$\begin{array}{c}\text { Department } \\
\text { Existing }\end{array}$} & \multicolumn{2}{|c|}{ Municipality } \\
\hline & & & Existing & Improvement \\
\hline \multirow[t]{4}{*}{ Exposure } & & & Drought magnitude & Media CHIRPS cells \\
\hline & & & Wet extremes & Media CHIRPS cells \\
\hline & & & Flood prone areas & $\begin{array}{l}\text { FPA/municipal sur- } \\
\text { face }\end{array}$ \\
\hline & & & Population density & $\mathrm{P}$ density in FPA \\
\hline \multirow{3}{*}{ Sensitivity } & & & Crop deficit & \\
\hline & & & $\begin{array}{l}\text { Farmers for self- } \\
\text { consumption }\end{array}$ & \\
\hline & $\begin{array}{l}\text { Food prices } \\
\text { Victims of disaster }\end{array}$ & & & $\rightarrow \bullet$ \\
\hline \multirow[t]{3}{*}{$\begin{array}{l}\text { Adaptive } \\
\text { capacity }\end{array}$} & & & $\begin{array}{l}\text { Local CCA plans } \\
\text { Rural accessibility } \\
\text { Irrigated agriculture }\end{array}$ & $\longrightarrow$ IRA \\
\hline & & $\begin{array}{l}\text { School enrolment } \\
\text { according gender } \\
\text { HIV Incidence }\end{array}$ & & \\
\hline & & & Cholera incidence & \\
\hline
\end{tabular}




\subsection{Conclusions}

The VICC at municipal scale for Haiti aggregates 10 indicators consistent with those proposed by the United Nations to monitor the SDGs (UNESC 2015): this is a reduced number compared to other vulnerability indices to $\mathrm{CC}$ on a local scale. Kept with just a few indicators, the VICC can easily be updated and allows central and local governments and the Official development aid to orient the measures for adaptation to $\mathrm{CC}$ to the most vulnerable sectors, to appreciate the improvements obtained years after year and to assess the impact and sustainability of local projects.

The data needed to measure the 10 indicators to prove the applicability of the VICC were downloaded from the websites of the ministries and those of other authorities, only with regard to information on precipitations that is not freely available in Haiti. This activity would be simplified if just one organisation were to be responsible for open access to information on climate change vulnerability on a municipal scale, such as CNIGS, CNSA, or ONEV-Observatoire National de l'Environnement et de la Vulnerabilité du Ministère de l'Environnement. This organization should update datasets on the vulnerability to $\mathrm{CC}$ of Haitian municipalities (useful farming surface area, farmers for self-consumption/Min. Agriculture, monthly cholera incidence/Ministry for Health), supplied always in the same format (maintaining 2009 as the year of reference for agricultural production) and completed (RAI data and not just the map/Ministry of Public works, transportation and communication).

In the future, the organisation in question could provide information on five additional factors of vulnerability to $\mathrm{CC}$ available: average monthly prices of food (expanding the number of markets currently monitored by the CNSA), forested (or reforested) area, at five-years intervals at least (CNIGS), victims and damages caused by hydro-meteorological disaster (Ministry of Interior and territorial communities), school enrolment according to gender (Ministry of National education), HIV incidence (Ministry of Health). Further expansions of the number of indicators could prevent the tracking of vulnerability and spatial coverage. 


\section{Annexe}

See Fig. 6.5 and Table 6.8

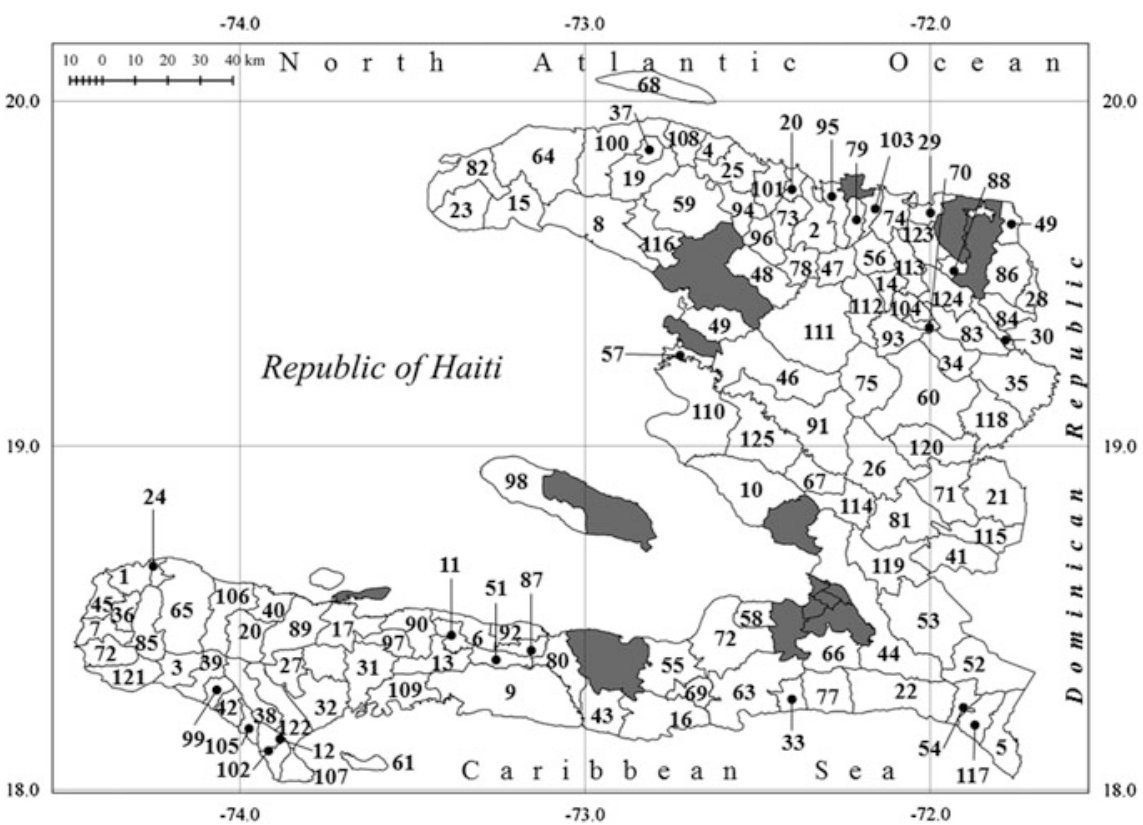

Fig. 6.5 Municipalities of Haiti: urban (grey) and rural (numbers) 


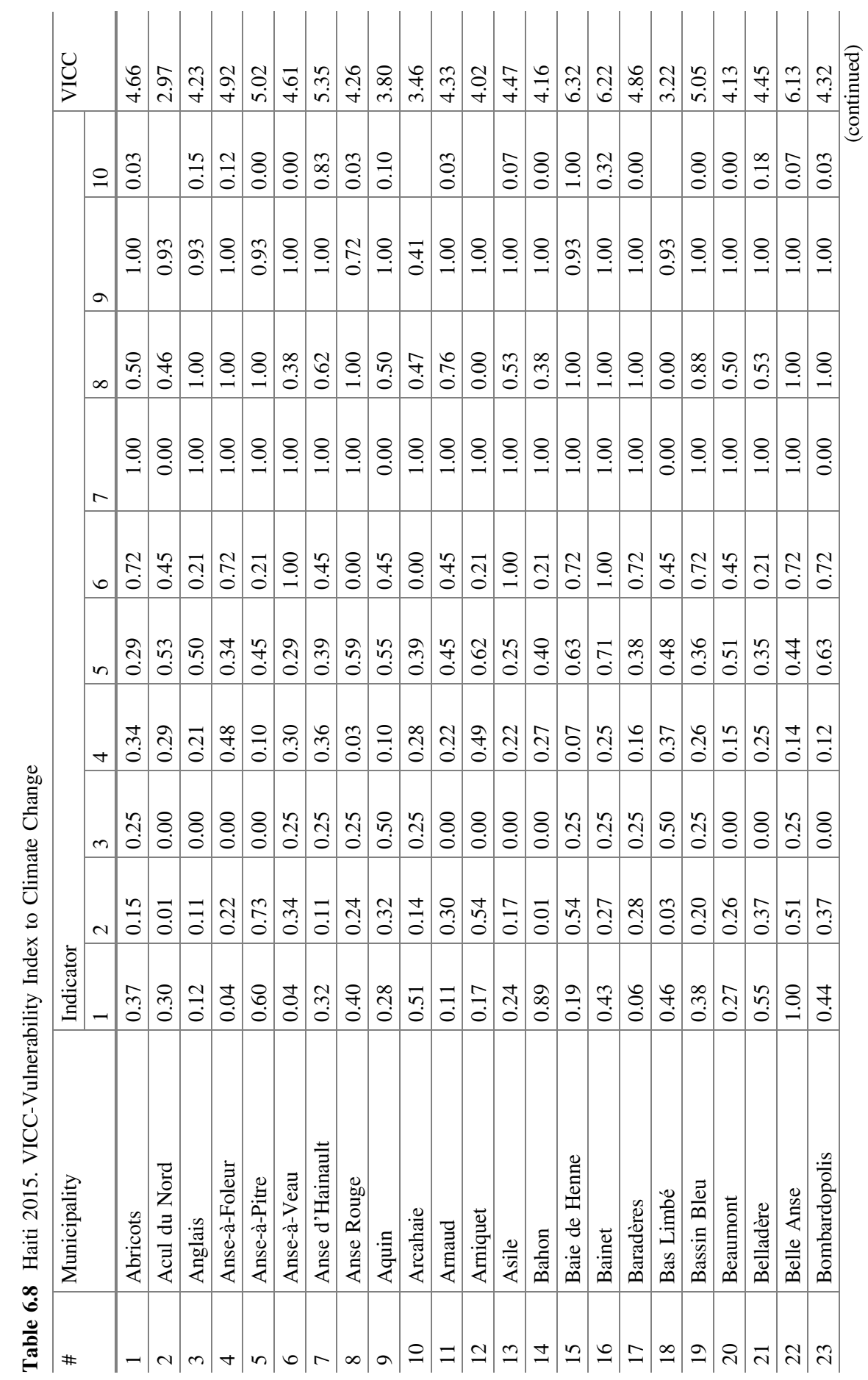




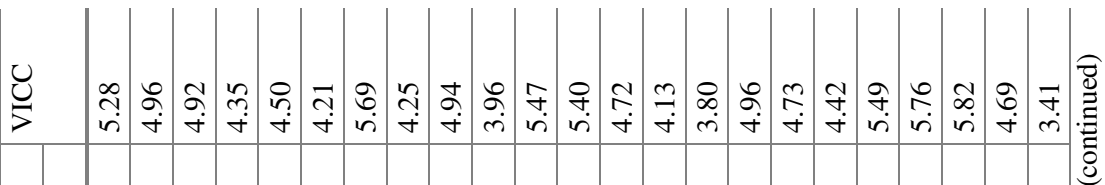

의

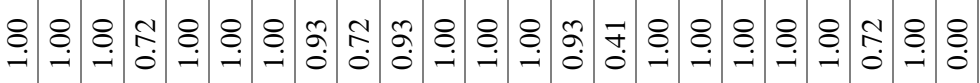

a

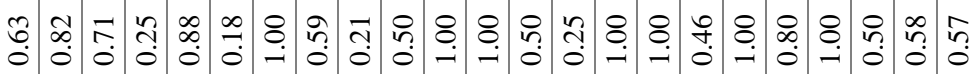

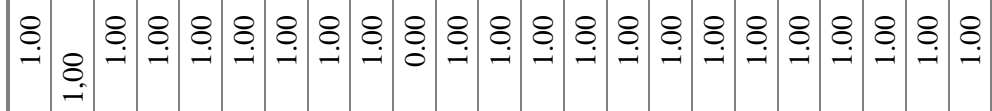

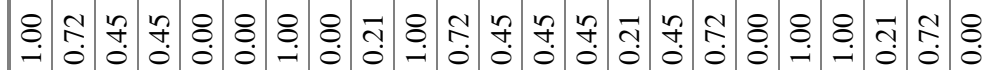

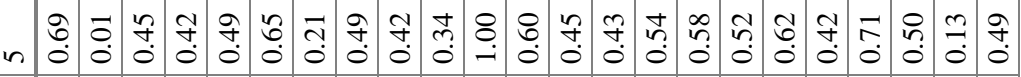

+

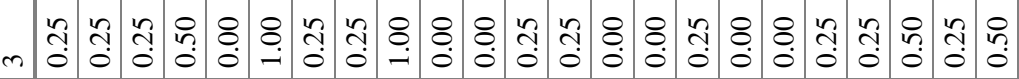

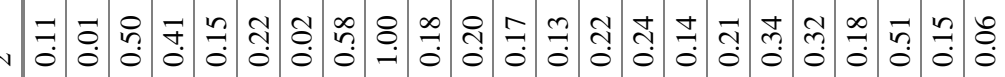
:

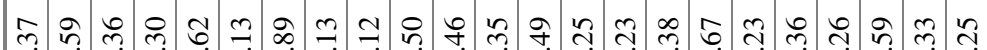
= - 


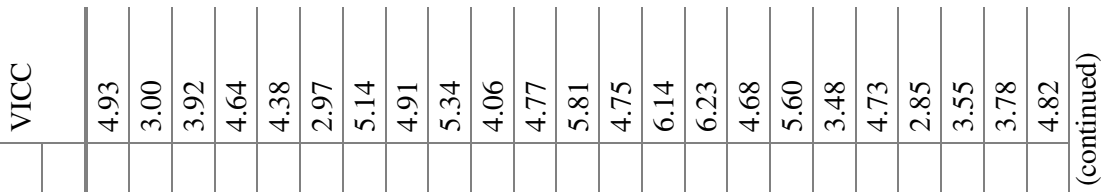

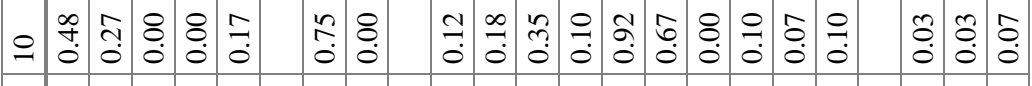

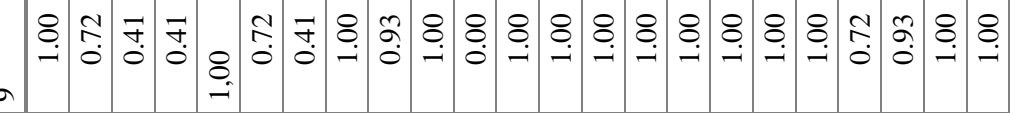

$a$

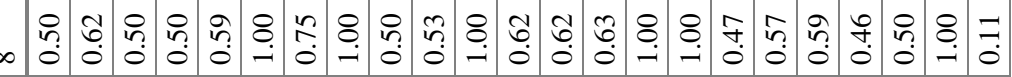

ஓ -

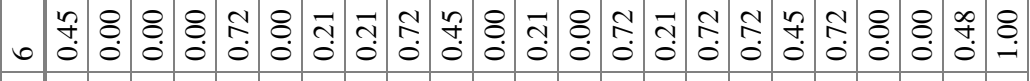

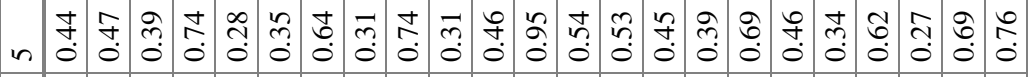

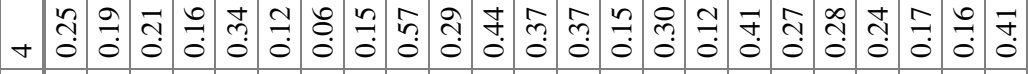

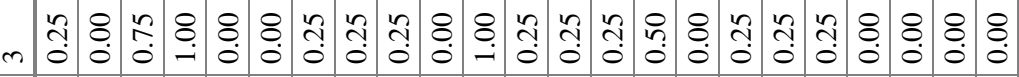

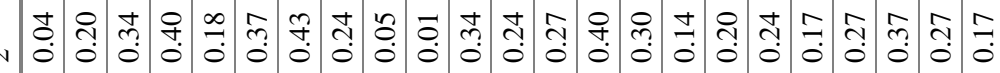

గn



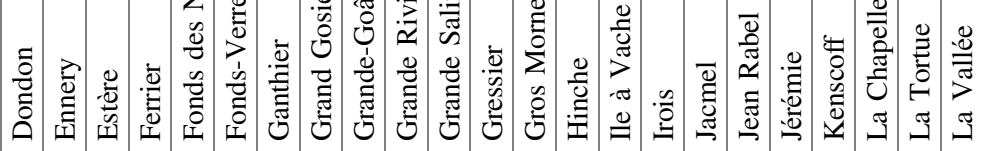

$\infty$

迹

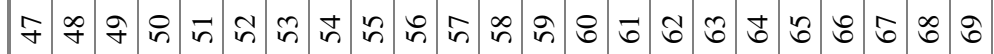




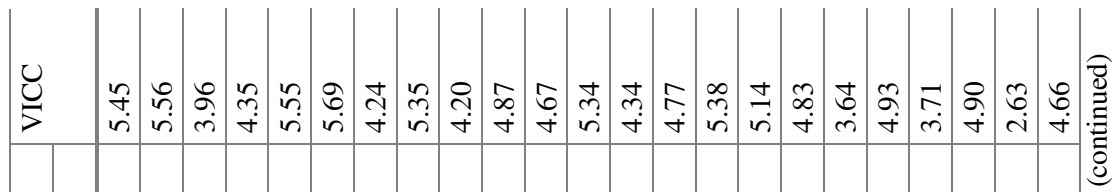

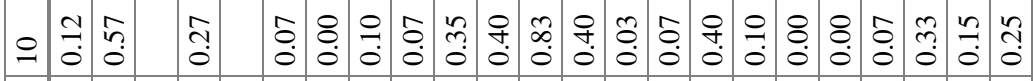

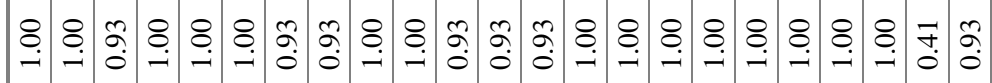

a

苞

ஓ $r$

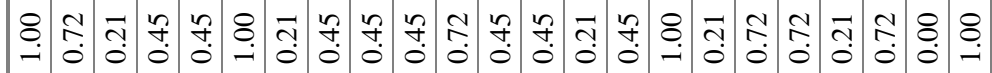

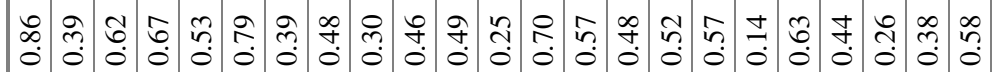

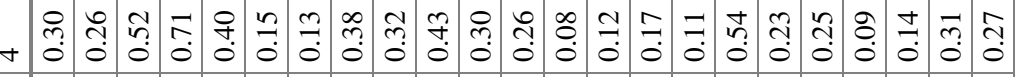

m

I

壳

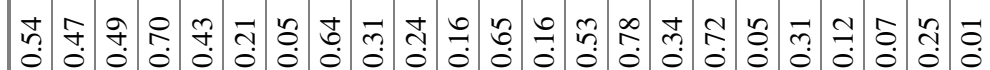

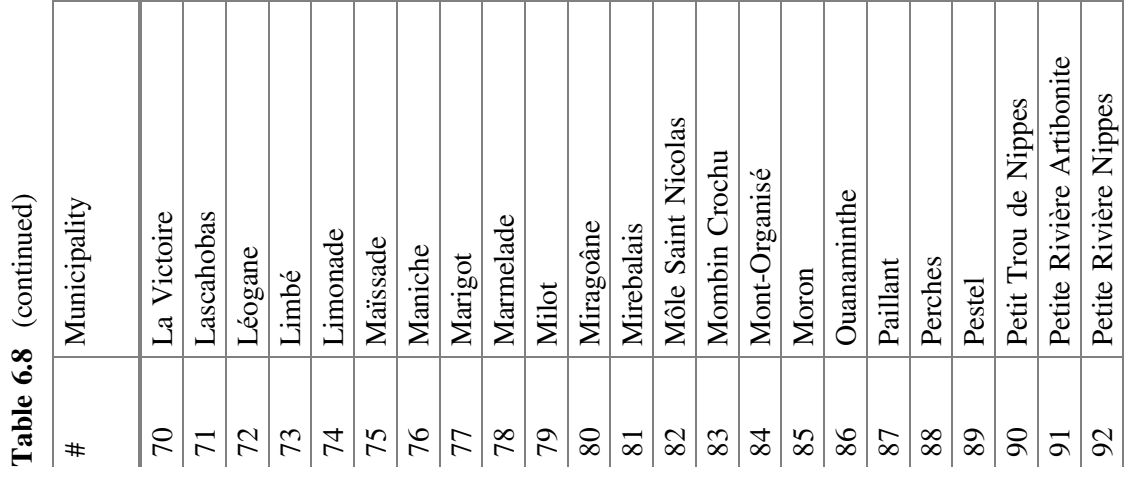




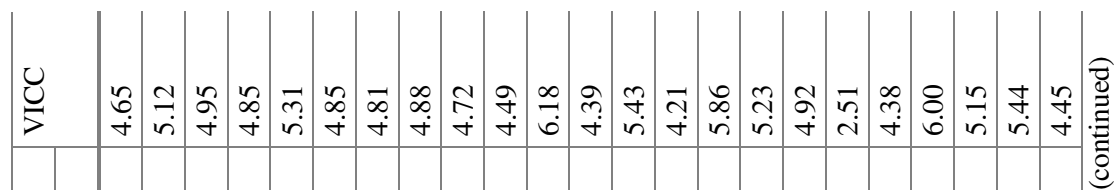

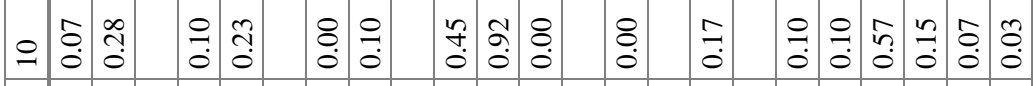

\&

$a$

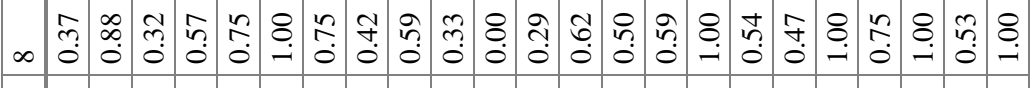

ஓ

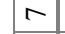

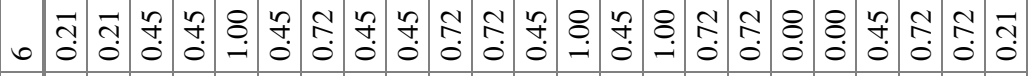

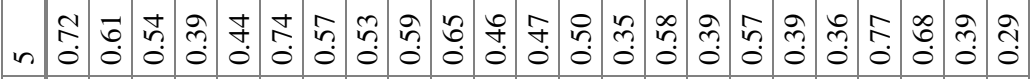

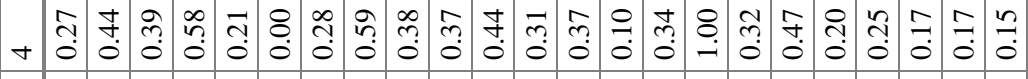

m

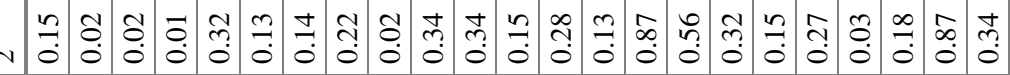

豙

ֻٕ:

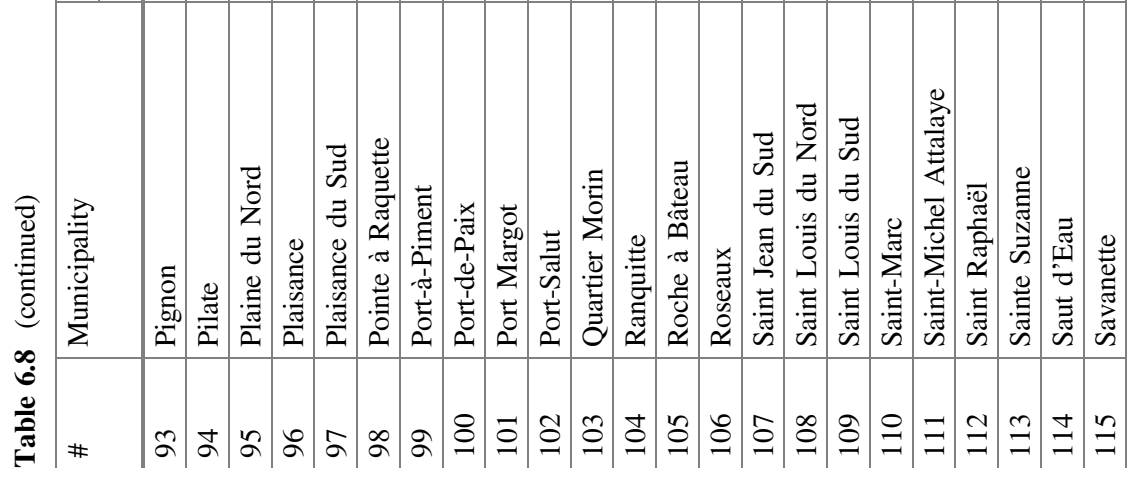




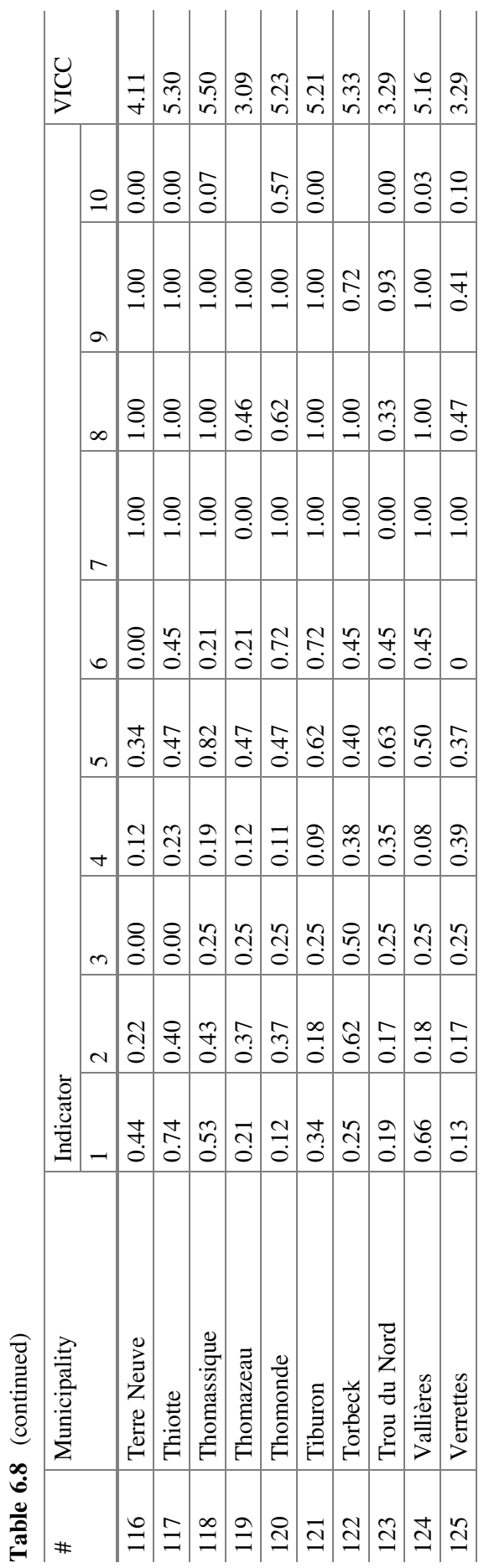




\section{References}

Adger, W.N., N. Brooks, G. Bentham, M. Agnew, S. Eriksen. 2004. New indicators of vulnerability and adaptive capacity. Tyndall Centre for Climate Change Research, technical report 7.

Ahsan, N., J. Warner. 2014. The socioeconomic vulnerability index: A pragmatic approach for assessing climate change led risks-A case study in the south-western coastal Bangladesh. International Journal of Disaster Risk Reduction 8: 32-49. doi:10.1016/j.ijdrr.2013.12.009.

Birkmann, J. 2006. Indicators and criteria dor measuring vulnerability: Theoretical bases and requirements. In Measuring vulnerability to natural hazards. Onwards disaster resilient societies, ed. J. Birkmann, 55-77. Tokyo-New York-Paris: UNU Press.

Borde, A., M. Huber, A. Goburdhun, A. Guidoux, E. Revoyron, E. Nsimba, J.A. Louis, A. Donjia, and J.-L. Kesner. 2015. Estimation des couts des impacts du changement climatique en Haiti. New York: PNUD-Ministère de l'économie et des finances.

Bollin, C., K. Fritzsche, S. Ruzima, S. Schneiderbauer, D. Becker, L. Pedoth, and S. Liersch. 2014. Analyse intégrée de la vulnerabilité au Burundi, vol. II. GIZ: Analyse de vulnérabilité au niveau local. Bujumbura.

Borja-Vega, C., A. de la Fuente. 2013. Municipal vulnerability to climate change and climate-related events in Mexico. Policy Research Working Paper 6417. Washington: The World Bank.

Ci Grasp 2.0. 2016. Glossary. http://www.pik-potsdam.de/cigrasp-2/bg/glossary.html\#S. Accessed 15 July 2016.

Etwire, P.M., R.M. Al-Hassan, J.K.M. Kuwornu, and Y. Osei-Owusu. 2013. Application of livelihood vulnerability index in assessing vulnerability to climate change and variability in Northern Ghana. Journal of Environment and Earth Science 3 (2): 157-170.

FAO, PAM. 2010. Mission FAO/PAM d'évaluation de la récolte et de la sécurité alimentaire en Haiti. Rome: FAO.

Frerichs, R.R. 2016. Deadly river. cholera and cover-un post-earthquake Haiti. Ithaca, NY: ILR Press.

Funk, C., P. Peterson, M. Landsfeld, D. Pedreros, J. Verdin, S. Shukla, G. Husak, J. Rowland, L. Harrison, A. Hoell, and J. Michaelsen. 2015. The climate hazards infrared precipitation with stations-A new environmental record for monitoring extremes. Scientific Data 2: 150066. doi:10.1038/sdata.2015.66.

Gbetibouo, G.A., C. Ringler, R. Hassan. 2010. Vulnerability of the South African farming sector to climate change and variability: An indicator approach. Natural Resources Forum 34: 175-187. doi:10.1111/j.1477-8947.2010.01302.x.

Hahn, M.B., A.M. Riederer, S.O. Foster. 2009. The livelihood vulnerability index: A pragmatic approach to assessing risks from climate varianbility and change-A case study in Mozambique. Global Environmental Change 19: 74-88. http://dx.doi.org/10.1016/j.gloenvcha.2008.11.002.

Heltberg, R., and M. Bonch-Osmolovskiy. 2010. Mapping vulnerability to climate change. Washington: The World Bank.

Hilden, M., A. Marx. 2013. Evaluation of climate change state, impact and vulnerability indicators, ETC CCA Technical paper 02/2013.

IPCC-International Panel on Climate Change. 2014. Annex II: Glossary. In Climate change 2014: synthesis report. Contribution of Working Groups I, II and III to the Fifth Assessment Report of the IPCC, eds. R.K. Pachauri, and L.A. Meyers, 117-130. Geneva: IPCC.

Nurse, L.A., R.F. McLean, J. Agard, L.P. Briguglio, V. Duvat-Magnan, N. Pelesikoti, E. Tompkins, and A. Webb. 2014. Small islands. In Climate Change 2014: Impacts, Adaptation, and Vulnerability. Part B: Regional Aspects. Contribution of Working Group II to the Fifth Assessment Report of the Intergovernmental Panel on Climate Change ed. V.R. Barros, C.B. Field, D.J. Dokken, M.D. Mastrandrea, K.J. Mach, T.E. Bilir, M. Chatterjee, K.L. Ebi, Y.O. Estrada, R.C. Genova, B. Girma, E.S. Kissel, A.N. Levy, S. MacCracken, P.R. Mastrandrea, 
and L.L. White, 1613-1654. Cambridge, United Kingdom and New York, USA: Cambridge University Press.

OCHA-United Nations Office for the Coordination of Humanitarian Affairs. 2016. Cholera remains an emergency and a priority fo the UN and its partners. Humanitarian Bulletin Haiti 57: 3-4.

PNUMA-ORLAC-Programa de las Naciones Unidas para el Medio Ambiente, Oficina Regional para América Latina y el Caribe. 2013. Análisis de vulnerabilidad e identificación de opciones de adaptación frente al cambio climático en el sector agropecuario y de recursos hídricos en Mesoamérica. PNUMA-ORLAC.

RdH-République d'Haiti. 2010. Analysis of Multiple Hazard in Haiti. Port-au-Prince, March.

RdH, MARNDR. 2012a. Atlas agricole d'Haïti. Enquête exploitation 2009. http://agriculture. gouv.ht/statistiques_agricoles/Atlas/preface.html. Accessed 16 Jun 2016.

RdH, MARNDR. 2012b. Politique d'irrigation du MARNDR 2012. Juin.

RdH, MARNDR. 2012c. Evaluation de la campagne agricole de printemps 2012. Septembre.

RdH, MARNDR. 2013. Evaluation previsionnelle de la performance des recoltes de la campagne agricole de printemps 2013.

RdH, MARNDR. 2014. Evaluation prévisionnelle de la performance des récoltes de la campagne agricole de printemps 2014. Octobre.

RdH, MARNDR CSA FEWS NET. 2009. Haiti: Cartographie de vulnerabilité multirisque juillet/aout 2009.

RdH, MEF, IHIS-Ministère de l'Economie et des Finances, Institut Haïtien de Statistique et d'Informatique. 2012. Population totale, population de 18 ans et plus ménages et densités éstimés en 2012. Port-au-Prince: DSDS.

RdH, MSPP-Ministère de la Santé Publique et de la Population. 2015. Infosanté. Bulletin d'information 1,9 , juillet.

RdH, MTPTC-Ministère des Travaux Publics, Transports et Communicartion. 2015. RAI (Rural Access Index) Haïti 2015. Accessibilité des sections communales au réseau routier, 6 mai http://www.mtptc.gouv.ht/media/upload/doc/publications/ROUTE_INDICE-RAI-2015.pdf. Accessed 16 Jun 2016.

Roberts, P., K.C. Shyam, C. Rastogi. 2006. Rural access index: A key development indicator. Transport Papers 10, March. The World Bank.

Schiavo-Campo, S. 1999. Strengthening "performance" in public expenditure management. Asian Review of Public Administration 11 (2): 23-44.

Sharma, B., N. Jangle. 2012. Assessing vulnerability to climate risk in Ahmednagar (Maharashtra) and Vaishah (Bihar) using GIS technique. In 13th Esri India User Conference 2012.

Tiepolo, M. 2009. Lo sviluppo delle aree rurali remote. Petrolio, uranio e governance locale in Niger. Milan: Franco Angeli.

Tuladhar, F.M. 2013. Climate change vulnerability index mapping of Nepal using NASA EOS Data. In 14th Esri India User Conference 2013.

UNESC-United Nations Economic and Social Council. 2015. Report of the inter agency and expert group on sustainable development goals indicators. https://unstats.un.org/unsd/statcom/ 47th-session/documents/2016-2-IAEG-SDGs-E.pdf. Accessed 16 Jun 1916.

UNESCO-IHE-Institute for Water Education. 2016. Flood vulnerability indices. http:// unescoihefvi.free.fr/vulnerability.php. Accessed 2 July 2016.

USAID. 2014. Design and use of composite indices in assessments of climate change vulnerability and resilience. Washington: USAID.

Verisk Maplecroft. 2016. Vulnerability Index. https://maplecroft.com/about/news/ccvi.html. Accessed 2 July 2016.

WMO-World Meteorological Organization, M. Svoboda, M. Hayes, and D. Wood. 2012. Standardized precipitation index user guide. Geneva: WMO.

World Bank. 2014. Open data for resilience initiative. World Bank: Field guide. Washington. 
Open Access This chapter is licensed under the terms of the Creative Commons Attribution 4.0 International License (http://creativecommons.org/licenses/by/4.0/), which permits use, sharing, adaptation, distribution and reproduction in any medium or format, as long as you give appropriate credit to the original author(s) and the source, provide a link to the Creative Commons license and indicate if changes were made.

The images or other third party material in this chapter are included in the chapter's Creative Commons license, unless indicated otherwise in a credit line to the material. If material is not included in the chapter's Creative Commons license and your intended use is not permitted by statutory regulation or exceeds the permitted use, you will need to obtain permission directly from the copyright holder.

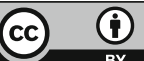

